\title{
Optimalisasi Penegakan Hukum Pidana Lingkungan melalui Putusan Hakim yang Berkepastian
}

DOI : $10.30595 /$ jhes.v\%vi\%i.9897

\section{Rizki Zakariya}

Sekolah Tinggi Hukum Indonesia Jentera, Email : rizkizakariya5@gmail.com

\begin{abstract}
Abstrak
Hakim di pengadilan memiliki peranan penting dalam penegakan hukum pidana di bidang lingkungan hidup. Akan tetapi, terdapat problematika dalam penegakan hukum oleh hakim dalam berbagai putusannya. Penelitian ini bertujuan untuk menguraikan dan analisis urgensi optimalisasi penegakan hukum pidana lingkungan melalui putusan hakim yang berkepastian. Kemudian menguraikan upaya yang dapat dilakukan dalam mengoptimalkan penegakan hukum pidana lingkungan oleh hakim. Metode penelitian yang digunakan dalam penelitian ini adalah deskriptif-kualitatif, dengan pendekatan kasus dan pendekatan undang-undang. Hasil penelitian ini menunjukan bahwa terdapat ketidakjelasan pendakwaan pidana pembakaran hutan dan lahan, ketidakjelasan batasan pelanggaran pidana, dan administrasi lingkungan, dan ketidakjelasan pemidanaan pemanfaatan hutan lindung. Atas permasalahan yang ditemukan tersebut, maka upaya yang dilakukan dalam mengoptimalkan penegakan hukum pidana dibidang lingkungan yakni dengan perubahan Peraturan Mahkamah Agung Nomor 13 Tahun 2016, perubahan UU No. 39 Tahun 2014, perubahan UU No. 32 Tahun 2009, dan penyusunan SEMA tentang Pedoman Pemidanaan Perkara Bidang Lingkungan Hidup oleh Mahkamah Agung. Melalui upaya penguatan tersebut, maka diharapka upaya penegakan hukum pidana lingkungan dapat berjalan optimal pada masa mendatang.
\end{abstract}

Kata-kata kunci : Optimalisasi, Penegakan Hukum, Pidana Lingkungan, Putusan, Kepastian Hukum.

\section{Abstract}

Judges in court have an important role in enforcing criminal law in the environmental sector. However, there are problems in law enforcement by judges in various decisions. This study aims to describe and analyze the urgency of optimizing environmental criminal law enforcement through a certain judge's decision. Then it describes the 
efforts that can be made in optimizing environmental criminal law enforcement by judges. The research method used in this research is descriptive-qualitative, with a case approach and a statute approach. The results of this study indicate the urgency of optimizing the enforcement of environmental criminal law through a judge's decision due to several reasons, including unclear charges for forest and land burning, unclear limits on criminal offenses and environmental administration, and unclear penalties for the use of protected forests. Due to the problems found, efforts were made to optimize criminal law enforcement in the environmental sector, namely by amending PERMA No. 13 of 2016, amendments to Law no. 39 of 2014, amendments to Law no. 32 of 2009, and the preparation of SEMA on Guidelines for Criminalization of Cases in the Environmental Sector by the Supreme Court. Through these recommended efforts, it is hoped that environmental criminal law enforcement efforts can run optimally in the future.

Keywords: Optimization, Law Enforcement, Environmental Crime, Judgment, Legal Certainty.

\section{Pendahuluan}

Setiap warga negara Indonesia berhak mendapatkan lingkungan hidup yang baik dan sehat. Hal itu sebagaimana dijamin dalam Pasal 28H ayat (1) UUD 1945. Jaminan hak warga negara peroleh lingkungan hidup yang sehat tersebut kemudian ditegaskan dalam Pasal 9 ayat (3) Undang-Undang No. 39 Tahun 1999 tentang Hak Asasi Manusia. Oleh sebab itu, negara harus mengupayakan terlindungi dan terpenuhi hak atas lingkungan yang sehat tersebut bagi segenap masyarakat Indonesia. Akan tetapi, hak tersebut sulit direalisasikan, karena berbagai praktik pencemaran dan perusakan lingkungan hidup di Indonesia. Hal itu dapat dilihat dari praktik deforestasi (perusakan hutan) dan emisi gas karbon yang terus meningkat setiap tahunnya. Dalam hal deforestasi, sepanjang 2015-2018 terdapat 3.403.000 hektar hutan Indonesia yang terbakar dan hilang (Greenpeace Indonesia, 2020). Kemudian dalam emisi gas karbon juga mengalami peningkatan, dari 516 juta ton gas karbon pada 2016, meningkat menjadi 543 juta ton gas karbon pada 2018 (Tim Publikasi, 2019). Kedua hal tersebut berdampak pada polusi udara yang meningkat di Indonesia. Lebih lanjut, dampaknya pada 2017 menyebabkan terjadinya 232 ribu jiwa kematian pada masyarakat Indonesia (CNN Indonesia, 2019). Hal itu disebabkan polusi udara berkontribusi pada 
$26 \%$ penyakit jantung akibat tersumbatnya pembuluh darah, $24 \%$ stroke, $43 \%$ penyakit paru obstruktif kronik, dan 29\% kanker paru-paru (Widowati, 2019). Berdasarkan uraian tersebut, maka akibat tidak terlindunginya lingkungan, sehingga menyebabkan polusi udara, mengancam keselamatan masyarakat. Olehkarenaitu, perluupaya optimal darinegara dalam melakukan pencegahan maupun penegakan hukum dalam rangka perlindungan lingkungan.

Penegakan hukum merupakan upaya untuk mewujudkan ide serta konsep menjadi kenyataan (Rahardjo, 2009). Selain itu, penegakan hukum bertujuan untuk menanggulangi kejahatan yang merugikan masyarakat, seperti perusakan dan pencemaran lingkungan (Rahardjo, 2009). Akan tetapi, dalam pelaksanaan penegakan hukum tersebut, masih terdapat problematika dalam melaksanakannya. Hal tersebut khususnya mengenai inkonsistensi hakim dalam memutus perkara pidana lingkungan di Indonesia, terutama dalam hal pertanggungjawaban pidana korporasi, delik undang-undang yang dipersalahkan, dan batasan pelanggaran pidana lingkungan dengan administrasi lingkungan. Sehingga hal tersebut merupakan latar belakang penelitian ini.

Kajian mengenai upaya optimalisasi penegakan hukum pidana lingkungan telah dilakukan oleh peneliti-peneliti sebelumnya. Setidaknya terdapat 3 (tiga) penelitian yang berkaitan dengan hal tersebut, yakni: Pertama, Nafi' Mubarok (2019) dalam temuannya menyatakan sebab tidak optimalnya penegakan hukum pidana lingkungan karena 2 (dua) hal yaitu struktur hukum dan substansi hukum. Pada struktur hukum, masalah itu mulai dari produk peradilan yang tidak sensitif dengan rasa keadilan di masyarakat, oknum pejabat lingkungan yang justru melakukan tindak pidana lingkungan, birokrasi pemerintah yang tidak sesnsitif pada premis ekologis, dan lemahnya infrastruktur penegak hukum. Sedangkan pada substansi hukum, kelemahan itu diantaranya persepsi aparat terhadap perkara lingkungan yang hanya kasus biasa, buruknya budaya hukum, kurangnya sosialisasi hukum lingkungan ke masyarakat, dan keterpurukan ekonomi (Mubarok, 2019). Kedua, menurut Muslim (2020) yang menyatakan, bahwa upaya optimalisasi penegakan hukum lingkungan dapat dilakukan dengan penerapan asas primum remedium untuk mekanisme pidana dalam perkara lingkungan. Sehingga pidana merupakan obat pertama untuk membuat 
jera orang melakukan pelanggaran yang diatur dalam undang-undang lingkungan (Muslim, 2020). Rekomendasi upaya optimalisasi penegakan hukum pidana lingkungan oleh Muslim berbeda dengan rekomendasi Lona Puspita (2018). Menurutnya dalam penegakan hukum pidana lingkungan, hukum pidana ditempatkan pada urutan terakhir (ultimum remedium), setelah mekanisme lain tidak dapat berjalan secara optimal dalam melindungi lingkunga (Puspita, 2018). Ketiga, Agung Setio Apriyanto (2014), menurutnya upaya optimalisasi penegakan hukum pidana lingkungan dapat dilakukan dengan meningkatkan profesionalitas dan kemampuan personel penyidik dalam melakukan penyidikan perkara pidana lingkungan. Kemudian menurutnya juga perlu ditingkatkan upaya pencegahan (prevenif) terjadinya pidana lingkungan. Hal itu dapat dilakukan dengan melakukan sosialisasi ke masyarakat, dan koordinasi dengan berbagai pihak (stakeholders) yang sering terlibat dalam upaya pencegahan itu (Apriyanto, 2014).

Berbeda dengan penelitian-penelitian sebelumnya tersebut. Setidaknya terdapat 2 (dua) hal yang membedakan penelitian penulis dengan penelitian sebelumnya. Pertama, penulis merekomendasikan optimalisasi penegakan hukum pidana lingkungan pada aspek konsistensi hakim di persidangan. Dimana putusan hakim sebagai mekanisme penegakan hukum terakhir memiliki kekuatan eksekutorial dalam penegakannya, serta bisa menjadi yurisprudensi bagi perkara serupa yang akan datang (Erwin, 2015). Sehingga bukan dalam tahap penyidikan seperti penelitian Agus Setio Apriyanto (2014) maupun penuntutan. Kedua, penulis fokus menguraikan mengenai permasalahan putusan hakim dalam memutus perkara pidana lingkungan. Sehingga bukan menguraikan kembali kedudukan mekanisme pidana dengan teori primum remedium maupun ultimum remedium dalam perkara lingkungan, seperti peneliti sebelumnya yakni Muslim (2020) dan Lona Puspita (2018).

Penelitian ini perlu dilakukan melihat kondisi pencemaran dan perusakan lingkungan hidup yang masif terus berlangsung di Indonesia, sebagaimana data di atas. Kemudian jaminan hak atas lingkungan hidup yang sehat bagi warga negara, serta kemampuan hukum untuk melindungi hak tersebut sebagai sosial kontrol, sosial engineering, dan sosial welfare (Diab, 2014). Tujuan penelitian ini terdiri atas 2 (dua) hal. Pertama, penulis mampu untuk 
menganalisis dan menguraikan urgensi dilakukannya optimalisasi penegakan hukum pidana lingkungan melalui putusan hakim yang berkepastian. Kemudian kedua, penulis mampu untuk menganalisis dan menguraikan upaya alternatif yang dapat dilakukan dalam optimalisasi penegakan hukum pidana lingkungan melalui putusan hakim yang berkepastian. Sehingga dengan dua tujuan tersebut, maka diharapkan upaya penegakan hukum pidana bidang lingkungan di Indonesia dapat terwujud secara optimal.

\section{Metode Penelitian}

Metode penelitian yang digunakan dalam penelitian ini ialah penelitian deskriptif kualitatif dengan pendekatan kasus (case approach), dan pendekatan undang-undang (statute approach). Pendekatan tersebut digunakan supaya pembahasan sesuai dengan focus ruang lingkup yang dituju. Peter Mahmud Marzuki, menyampaikan bahwa pendekatan kasus adalah pendekatan yang dilakukan dengan cara melakukan telaah terhadap kasus-kasus yang berkaitan dengan isu yang dihadapi terkait hukum, dalam hal ini melalui putusan yang dianalisis (Marzuki, 2011). Sedangkan pendekatan undangundang dilakukan dengan menelaah semua undang-undang atau regulasi yang terkait dengan penelitian yang diteliti (Johny, 2007). Penelitian deskriptif kualitatif adalah suatu metode dalam meneliti status sekelompok manusia, suatu objek dengan tujuan memuat deskripsi, gambaran, atau lukisan secara sistematis, factual, dan akurat, mengenai fakta atau fenomena yang sedang diselidiki (Sevilla, 1993).

Kemudian penulis menggunakan 2 (dua) sumber data yang diperoleh melalui penelitian kepustakaan (library research). Ketiga bahan hukum sebagai sumber data tersebut diantaranya: Pertama, bahan hukum primer. Dimana penulis melakukan kajian dan telaah berbagai peraturan perundangundangan, mulai dari UUD 1945, Undang-Undang No. 8 Tahun 1981 tentang Kitab Undang-Undang Hukum Acara Pidana, Undang-Undang No. 32 Tahun 2009 tentang Perlindungan dan Pengelolaan Lingkungan Hidup, UndangUndang No. 41 Tahun 1999 tentang Kehutanan, Undang-Undang No. 18 Tahun 2013 tentang Pencegahan dan Pemberantasan Perusakan Hutan, Undang-Undang No. 4 Tahun 2009 tentang Pertambangan Mineral dan Batubara, Undang-Undang No. 22 Tahun 2001 tentang Minyak dan Gas Bumi, 
Undang-Undang No. 5 Tahun 1990 tentang Konservasi Sumber Daya Alam Hati dan Ekosistemnya, Undang-Undang No. 31 Tahun 2004 Jo. UU No. 45 Tahun 2009 tentang Perikanan, Undang-Undang No. 12 Tahun 1992 tentang Sistem Budidaya Tanaman, dan Undang-Undang No. 39 Tahun 2014 tentang Perkebunan. Kedua, bahan hukum sekunder. Bahan hukum sekunder yang digunakan dalam penelitian ini terdiri dari analisis berbagai Putusan pidana bidang lingkungan hidup di pengadilan tingkat pertama, dengan register "LH." Putusan tersebut diperoleh melalui situs direktori putusan Mahkamah Agung yang diakses secara online. Kemudian digunakan juga laporan yang dipublikasikan maupun tidak dipublikasikan oleh lembaga atau individu, yang meliputi pendapat hukum/doktrin/teori yang diperoleh dari buku, laporan penelitian, jurnal, karya ilmiah, laporan tahunan, dan artikel pada berbagai majalah, website, dan jurnal ilmiah.

Atas data-data yang terkumpul tersebut, selanjutnya dilakukan pengolahan data dengan 4 (empat) tahapan. Pertama, editing, yakni pemeriksaan ulang bahan hukum mulai dari kelengkapan, kejelasan makna, kesesuaian, dan relevansi dengan isu terkait penelitian. Kemudian kedua coding, yakni pemberian catatan yang menyatakan jenis sumber bahan hukum (buku, jurnal, undang-undang, penelitian, dan sebagainya); dan pemegang hak cipta (nama penulis dan tahun terbit). Selanjutnya ketiga, merekonstruksi, yakni menyusun ulang baha-bahan sumber penelitian secara teratur, urut, dan logis. Sehingga mudah untuk dipahami dan interpretasikan. Selanjutnya keempat, sistematisasi bahan hukum, yakni menempatkan bahan hukum secara berurutan berdasar kerangka sistematika pembahasan yang mengacu pada urutan masalah.

\section{Hasil dan Pembahasan}

\section{Peran Mahkamah Agung dalam Penanganan Perkara Pidana Bidang Lingkungan}

Mahkamah Agung merupakan lembaga penyelenggara kekuasaan kehakiman pada semua lingkungan peradilan di Indonesia (Pasal 2 UU No. 4/2004). Dalam menjalankan tugasnya tersebut hakim-hakim di Mahkamah Agung diberi kewenangan untuk memeriksa, mengadili, dan memutus 
perkara pidana tanpa campur tangan pihak lain (Pasal 18 ayat (1) UU No. 4/2004). Lebih lanjut, prinsip dalam penanganan perkara pidana oleh hakim di peradilan tersebut yakni sederhana, cepat, dan biaya ringan (Ilham, 2018).

Mahkamah Agung sebagai lembaga peradilan, adalah bagian dari sistem penegakan hukum pidana di Indonesia. Kewenangan peradilan memutus perkara pidana itu sebagaimana ditegaskan dalam Pasal 1 angka 9 UndangUndang No. 8 Tahun 1981 tentang Kitab Undang-Undang Hukum Acara Pidana (KUHAP). Terlebih sejak tahun 2011, telah diatur adanya kamar pidana di Mahkamah Agung yang ditangani oleh hakim khusus pidana, melalui Keputusan Ketua Mahkamah Agung RI No. 142/KMA/SK/IX/2011 Tentang Pedoman Penerapan Sistem Kamar di Mahkamah Agung. Pemisahan kamar pidana tersebut dilakukan untuk menjaga kualitas dan konsistensi putusan Mahkamah Agung. Sehingga hakim di Mahkamah Agung dapat mengadili perkara sesuai dengan bidang kompetensi yang dimilikinya (SK KMA No. 142/KMA/SK/IX/2011). Lebih lanjut, adanya sistem kamar bertujuan untuk menciptakan keadilan dan kepastian hukum di masyarakat (Machmudin, 2015).

Pidana lingkungan merupakan salah satu perkara yang diperiksa, diadili, dan diputus oleh hakim-hakim di Mahkamah Agung, baik di tingkat pertama (Pengadilan Negeri), kedua (Pengadilan Tinggi), maupun terakhir (Mahkamah Agung). Perlu dipahami, bahwa yang dimaksud dengan perkara lingkungan, ruang lingkupnya di Mahkamah Agung diatur dalam Pasal 5 ayat (3) Keputusan Ketua Mahkamah Agung No. 134/KMA/SK/IX/2011 tentang Sertifikasi Hakim Lingku-ngan Hidup, yang meliputi:

a. Pelanggaran terhadap peraturan administrasi di bidang perlindungan dan pengelolaan lingkungan hidup, termasuk tetapi tidak terbatas pada peraturan di bidang kehutanan, perkebunan, pertambangan, pesisir dan kelautan, tata- ruang, sumber daya air, energi, perindustrian, dan/atau konservasi sumber daya alam; dan

b. Pelanggaran ketentuan perdata dan pidana di bidang perlindungan dan pengelolaan lingkungan hidup, termasuk tetapi tidak terbatas pada peraturan di bidang kehutanan, perkebunan, pertambangan, pesisir dan kelautan, tata ruang, sumber daya air, energi, perindustrian, dan/atau 
konservasi sumber daya alam.

Lebih jauh, Mahkamah Agung melakukan penggolongan perkara pidana lingkungan hidup melalui SK KMA Nomor 037/KMA/SK/III/2015. Sehingga pada perkara pidana lingkungan hidup akan diberi kode " $\mathrm{LH}$ " dalam register nomor perkaranya. Adapun undang-undang yang mengatur perkara pidana lingkungan hidup dan masuk ruang lingkup register lingkungan hidup tersebut diantaranya:

a. Undang-Undang No. 32 Tahun 2009 tentang Perlindungan dan Pengelolaan Lingkungan Hidup;

b. UU No. 41 Tahun 1999 tentang Kehutanan;

c. UU No. 18 Tahun 2013 tentang Pencegahan dan Pemberantasan Perusakan Hutan;

d. UU No. 4 Tahun 2009 tentang Pertambangan Mineral dan Batubara;

e. UU No. 22 Tahun 2001 tentang Minyak dan Gas Bumi;

f. UU No. 5 Tahun 1990 tentang Konservasi Sumber Daya Alam Hati dan Ekosistemnya;

g. UU No. 31 Tahun 2004 Jo. UU No. 45 Tahun 2009 tentang Perikanan;

h. UU No. 12 Tahun 1992 tentang Sistem Budidaya Tanaman; dan

i. UU No. 39 Tahun 2014 tentang Perkebunan.

Berdasarkan hal tersebut, maka ruang lingkup perkara pidana lingkungan tersebut luas, bukan hanya yang diatur dalam UU PPLH, melainkan juga berbagai undang-undang lainnya. Adapun rincian perkara pidana lingkungan yang diputus oleh pengadilan selama kurun waktu 2013-2019 dapat dilihat pada grafik berikut (LeIP, 2020): 
Tabel 1 : Putusan Perkara Bidang Lingkungan selama 2013-201

\begin{tabular}{lcccccccc}
\hline Undang-Undang & 2013 & 2014 & 2015 & 2016 & 2017 & 2018 & 2019 & Total \\
\hline PPLH & 2 & 2 & 1 & 13 & 10 & 7 & 18 & 59 \\
Kehutanan & 0 & 0 & 1 & 29 & 42 & 86 & 62 & 220 \\
Pertambangan & 0 & 0 & 0 & 9 & 10 & 36 & 15 & 70 \\
Perkebunan & 0 & 0 & 0 & 0 & 4 & 11 & 11 & 26 \\
Perikanan & 0 & 0 & 0 & 0 & 1 & 3 & 4 & 8 \\
Konservasi SDA & 0 & 0 & 0 & 1 & 1 & 23 & 18 & 43 \\
Migas & 0 & 0 & 0 & 0 & 0 & 3 & 5 & 8 \\
Budidaya Tanaman & 0 & 0 & 0 & 0 & 0 & 1 & 0 & 1 \\
Karantina Hewan & 0 & 0 & 0 & 0 & 0 & 1 & 0 & 1 \\
Jumlah & 2 & 2 & 8 & 52 & 68 & 171 & 133 & 436 \\
\hline
\end{tabular}

Berdasarkan tabel 1, maka diketahui perkara lingkungan yang diputus oleh pengadilan di Indonesia cenderung meningkat setiap tahunnya. Dimana pada tahun 2013 hanya ada 2 perkara pidana lingkungan, kemudian naik menjadi 133 perkara pada 2019. Hal itu menunjukan semakin optimalnya upaya penegakan hukum pidana pada perkara lingkungan. Kemudian dari proses penegakan hukum pidana lingkungan tersebut, diketahui rincian amar putusan hakim terhadap Terdakwa, yakni 382 perkara dinyatakan bersalah, 10 perkara dinyatakan lepas, 43 perkara dinyatakan bebas, dan 1 perkara dinyatakan tidak dapat diterima (Niet Ontvankelijke Verklaard/NO) (LeIP, 2020), akan tetapi dalam pelaksanaan penegakan hukum pidana lingkungan oleh hakim tiap putusan-putusan tersebut masih memiliki beberapa permasalah. Permasalahan itu diuraikan sebagai berikut.

\section{Ketidakjelasan Pertanggungjawaban Pidana Lingkungan oleh Korporasi}

Sepanjang 2013-2019 setidaknya terdapat 26 putusan pidana lingkungan terkait korporasi. Dari keseluruhan kasus tersebut, yang dijadikan Terdakwa terdiri atas beberapa pihak, diantaranya: pengurus korporasi (9 putusan), pegawai (setara manajer) korporasi (1 putusan), pimpinan cabang (1 putusan), dan pengurus serta pegawai korporasi secara bersama-sama (1 putusan). Kemudian terdapat beberapa tindak pidana yang dijerat terkait korporasi. Dalam hal dakwaan dengan UU PPLH, perbuatan pidana tersebut mulai dari pembakaran lahan, illegal dumping, melakukan kegiatan usaha 
tanpa izin lingkungan, dan mengelola limbah B3. Sedangkan pada dakwaan UU Kehutanan, tindak pidananya berupa pengangkutan hasil hutan secara illegal.

Permasalahan pertanggungjawaban pidana korporasi kasus lingkungan, yakni kapan pembebanan tanggungjawaban itu diberikan untuk korporasi atau pengurus korporasi. Hal itu karena dalam Putusan No. 1199 K/Pid. Sus.LH/2016, yang merupakan tindak pidana korporasi korporasi, namun dengan Terdakwa direktur, wakil direktur, dan pegawai bidang lingkungan PT Pusaka Jaya Palu Power. Kemudian kasus tindak pidana korporasi lain dalam Putusan Kasasi No. 2733 K/Pid.Sus.LH/2016, yang menjadi terdakwa adalah Chairul Anam selaku direktur perusahaan PT Harapan Sembilan, yang melakukan pengelolaan oli dan aspak bekas tanpa izin. Ketidakjelasan pertanggungjawaban pidana korporasi namun dengan yang dipidana adalah pengurus korporasi tersebut, dapat diketahui dari pertimbangan Mahkamah Agung dalam Putusan No. 2303 K/Pid.Sus.LH/2016 berikut:

"Bahwa, alasan pertimbangan tersebut tidak sesuai dengan ketentuan tentang struktur dan tanggungjawab pimpinan (cabang) perusahaan. Sebagai seorang pimpinan bertanggungjawab atas seluruh kegiatan atau pelaksanaan perusahaan yang dipimpinnya. Bukankah dalam ketentuan Undang-Undang Perseroan Terbatas telah ditentukan bahwa Direktur bertanggungjawab mewakili perusahaan, baik dalam maupun di luar pengadilan. Judex Facti tidak boleh melepaskan tanggungjawab pidana Terdakwa I selaku pimpinan cabang PT. National Sago Prima (PT.NSP);

Bahwa, terlepas dari alasan apakah Terdakwa I memahami atau tidak mengerti soal pabrik dan limbah pabrik B3, tidak dapat menjadi alasan menghilangkan tanggungjawab pidana Terdakwa I.

Bahwa perusahaan cabang PT. National Sago Prima (PT.NSP) yang dipimpin Terdakwa adalah bergerak dibidang pengelolaan tahu yang menggunakan alat pengelolaan berupa pabrik. Sehingga suka atau tidak masalah atau residu yang ditimbulkan dari hasil pengelolaan pabrik menjadi tanggungjawab Terdakwa I maupun Terdakwa II selaku manager pabrik"

Ketidakjelasan pertanggungjawaban pidana korporasi tersebut yakni tidak adanya indikator yang digunakan dalam menentukan suatu tindak pidana korporasi dapat menjerat juga pengurus di dalamnya, atau hanya korporasi. Hal itu karena dari 9 putusan yang mendakwa korporasi sebagai Terdakwa, seluruhnya dituntut penjara dan denda terhadap pengurusnya. 
Dari kasus tersebut, maka apabila benar hanya menjerat korporasi, maka pidana yang dijatuhkan hanya denda, bukan pemenjaraan. Permasalahan tersebut belum terselesaikan, terlebih Peraturan Mahkamah Agung No. 13 Tahun 2016 tentang Tata Cara Penanganan Tindak Pidana oleh Korporasi, tidak mengatur mengenai indikator yang digunakan untuk menentukan kapan suatu tindak pidana korporasi dapat menjerat korporasi, pengurus korporasi, atau bahkan keduanya secara bersa-sama. Kondisi permasalahan yang terjadi tersebut berimplikasi pada tidak adanya kepastian hukum di masyarakat mengenai pertanggungjawaban pidana korporasi.

\section{Ketidakjelasan Pendakwaan Pidana Perkara Pembakatan Hutan dan Lahan}

Sepanjang 2013-2019, ditemukan terdapat 35 putusan pidana kebakaran hutan dan lahan. Dari jumlah tersebut, 10 perkara diputus menggunakan UU PPLH; 17 perkara diputus dengan UU No. 39 Tahun 2014 tentang Pekebunan; dan 8 perkara diputus dengan UU No. 41 Tahun 1999 tentang Kehutanan. Banyaknya undang-undang yang digunakan dalam mempidana perbuatan pembakaran hutan dan lahan tersebut menunjukan adanya ketidakjelasan dan ketidakpastian UU mana yang digunakan.

Ketidakjelasan pendakwaan perbuatan pidana pembakaran hutan dan lahan tersebut dapat ditemukan antara Putusan No. 277 K/Pid.Sus-LH/2016 dan 340/Pid.B-LH/2018/PN.Bkn. Apabila dalam Putusan No. 277 K/Pid.SusLH/2016 terdakwa dipidana dengan Pasal 108 UU PPLH, karena perbuatannya membakar lahan miliknya sendiri seluas 3 hektar namun menjalar, sehingga menyebabkan kebakaran hutan. Sedangkan pada Putusan No. 340/Pid.BLH/2018/PN.Bkn, yang perbuatannya serupa tersebut, justru dijerat dengan Pasal 108 UU Perkebunan. Adanya ketidakjelasan pendakwaan pidana kebakaran hutan dan lahan dalam 2 undang-undang tersebut disebabkan tumpang tindih peraturan yang mengatur hal yang sama. Dimana Pasal 108 Pasal UU PPLH berbunyi sebagai berikut:

"Setiap orang yang melakukan pembakaran lahan sebagaimana dimaksud dalam Pasal 69 ayat (1) huruf $h$, dipidana dengan pidana penjara paling singkat 3 (tiga) tahun dan paling lama 10 (sepuluh) tahun dan denda paling sedikit Rp3.000.000.000,00 (tiga miliar rupiah) dan paling banyak Rp10.000.000.000,00 
(sepuluh miliar rupiah)."

Kemudian hal serupa juga diatur dalam Pasal 108 UU Perkebunan, yang berbunyi sebagai berikut:

"Setiap Pelaku Usaha Perkebunan yang membuka dan/atau mengolah lahan dengan cara membakar sebagaimana dimaksud dalam Pasal 56 ayat (1) dipidana dengan pidana penjara lama 10 (sepuluh) tahun dan denda paling banyak Rp10.000.000.000,00 (sepuluh miliar rupiah)."

Adanya dua undang-undang mengatur hal yang sama dalam pemidanaan pelaku pembakaran hutan dan lahan tersebut menyebabkan tidak adanya kepastian hukum di masyarakat. Padahal antara kedua undang-undang yang mengatur hal yang sama, namun justru hukuman yang diancamkan berbeda. Apabila dalam UU PPLH, diatur ancaman minimal Rp. 3 Miliar, sedangkan dalam UU Perkebunan tidak diatur minimal tersebut. Perbedaan ancaman hukuman itu menimbulkan efek jera dan rasa keadilan di masyarakat yang dirugikan juga berbeda.

\section{Ketidakjelasan Batasan Pelanggaran Pidana Lingkungan dan Administrasi Lingkungan}

Selanjutnya terdapat ketidakjelasan batasan pelanggaran pidana lingkungan dengan administrasi lingkungan. Hal itu diketahui dari putusan pidana lingkungan yang dianalisis dan sebenarnya adalah pelanggaran administrasi lingkungan, namun berujung pada pemidanaan. Kasus lingkungan yang sering ditemui yakni pada perbuatan illegal dumping, pengelolaan limbah B3 tanpa izin, dan menjalankan usaha tanpa izin lingkungan.

Praktik ketidakjelasakan batasan pelanggaran pidana dan administrasi tersebut dapat diketahui dari Putusan No. 2733 K/Pid.Sus-LH/2016 dan Putusan No. 40/Pid.B/LH/2019/PN.Grt. Dalam Putusan No. 2733 K/Pid. Sus-LH/2016, Terdakwa Chairul Anam dipidana penjara 1 tahun karena perusahaan pengelola oli bekas dan limbah aspal miliknya sejak 2015 dioperasionalkan tanpa memiliki izin penampungan limbah. Sehingga atas hal itu, Terdakwa dipidana dengan Pasal 102 UU PPLH, terkait pidana pengelolaan limbah B3 tanpa izin. Sementara itu, pada Putusan No. 40/Pid.B/ 
LH/2019/PN.Grt, Terdakwa Kuswendi, dipidana karena usaha camping ground miliknya dijalankan tanpa memiliki izin lingkungan (AMDAL). Perbuatannya itu dijerat dengan Pasal 109 UU PPLH, mengenai melakukan usaha tanpa izin lingkungan. Hal yang menjadi masalah adalah perbuatan Terdakwa membangun camping ground dilokasi yakni dalam kapasitasnya sebagai Kepala Dinas Pemuda dan Olahraga Kabupaten Garut, sehingga bersifat administrasi.

Perlu dipahami bahwa rumusan delik Pasal 102, Pasal 104, dan Pasal 109 UU PPLH mengatur mengenai pemidanaan suatu kegiatan usaha tanpa izin. Ketiga delik tersebut mengakomodir dilakukannya pemidanaan langsung tanpa melalui skema administrasi terlebih dahulu, seperti Pasal 100 ayat (1) UU PPLH. Akan tetapi, pada kasus dua putusan tersebut sebenarnya dapat dikenakan dengan tindakan administrasi yang diatur sanksinya dalam Pasal 76 UU PPLH sampai dengan Pasal 83 UU PPLH. Pasal administrasi yang dapat dikenakan pada perbuatan tersebut salah satunya Pasal 80 ayat (2) UU PPLH, yang berbunyi:

"Pengenaan paksaan pemerintah dapat dijatuhkan tanpa didahului teguran apabila pelanggaran yang dilakukan menimbulkan: a. ancaman yang sangat serius bagi manusia dan lingkungan hidup; $b$. dampak yang lebih besar dan lebih luas jika tidak segera dihentikan pencemaran dan/atau perusakannya; dan/atau c. kerugian yang lebih besar bagi lingkungan hidup jika tidak segera dihentikan pencemaran dan/atau perusakannya."

Dalam UU PPLH, tidak diatur mengenai parameter dan syarat yang jelas mengenai ukuran suatu pelanggaran dapat dijerat dengan pidana atau administrasi. Halitu menimbulkan ketidakpastian, terlebih dalam pelanggaran terkait ketiadaan izin kegiatan usaha tersebut dampaknya banyak merugikan masyarakat atas aktivitas usahanya, sehingga perlu kepastian hukum bagi masyarakat dalam melaporkan dan tindak lanjutnya.

\section{Pemidanaan Pemanfaatan Hutan Lindung oleh Warga Setempat}

Dari berbagai putusan tersebut, ditemukan terdapat masalah dalam pemidanaan perbuatan pemanfaatan hutan lindung oleh warga setempat. Permasalahan itu setidaknya ditemukan dalam Putusan No. 1367 K/Pid.SusLH/2016, Putusan No. 2641 K/Pid.Sus-LH/2016, dan Putusan No. 2647 K/Pid. 
Sus-LH2016. Dimana ketiga putusan tersebut memiliki 2 (dua) kesamaan, yakni perbuatan Terdakwa memanfaatkan hutan tanpa izin pejabat yang berwenang, baik dengan menebang maupun membuka lahan perkebunan; dan Terdakwa tinggal di dalam kawasan hutan tersebut. Dalam ketiga putusan tersebut, Mahkamah Agung menyatakan bahwa perbuatan Terdakwa bukan tindak pidana, sekalipun perbuatannya tanpa memiliki izin. Hal itu berlainan dengan Putusan No. 2095 K/Pid.Sus-LH/2017 yang memiliki karakter perbuatan serupa. Dimana Terdakwa Abdul Rohim, oleh Mahkamah Agung justru dinyatakan bersalah melakukan perbuatan pidana pemanfaatan hutan lindung tanpa izin. Sehingga atas perbuatannya, Terdakwa dijatuhi hukuman pidana penjara selama 1 tahun.

Berdasarkan perbandingan tersebut, maka diketahui ada inkonsistensi hakim di Mahkamah Agung dalam memutus perkara pemanfaatan hutan lindung tanpa izin. Kondisi tersebut menunjukan tidak adanya kepastian hukum bagi masyarakat, yang umumnya memanfaatkan itu untuk kepentingan hidupnya dalam skala kecil. Bersumber pada uraian tersebut di atas, maka diketahui terdapat 4 (empat) permasalahan dalam penegakan hukum pidana lingkungan oleh hakim dalam putusannya. Masalah itu mulai dari ketidakjelasan pertanggungjawaban pidana korporasi, ketidakjelasaan pendakwaan pidana perkara pembakaran hutan dan lahan, ketidakjelasan batasan pelanggaran pidana lingkungan dan administrasi lingkungan, dan ketidakjelasan pemidanaan pemanfaatan hutan lindung oleh warga setempat.

\section{Upaya yang Dapat Dilakukan dalam Optimalisasi Penegakan Hukum Pidana Lingkungan melalui Putusan Hakim yang Berkepastian}

Berlandaskan empat permasalahan tersebut, maka perlu alternatif solusi dalam menyelesaikan problematika tersebut. Sehingga dengan upaya tersebut, maka optimalisasi penegakan hukum pidana lingkungan melalui putusan hakim yang berkeadilan dapat tercapai. Adapun upaya yang dapat dilakukan diantaranya:

a. Perbaikan Peraturan Mahkamah Agung No. 13 Tahun 2016 tentang Tata Cara Penanganan Tindak Pidana oleh Korporasi

PERMA 13/2016 merupakan pedoman hakim mengadili perkara tindak 
pidana oleh korporasi. Hal itu sebagaimana ditegaskan dalam Pasal 2 huruf a PERMA 13/2016, yang menyatakan bahwa:

"Maksud dan tujuan pembentukan tata cara penanganan perkara tindak pidana oleh Korporasi adalah untuk: menjadi pedoman bagi penegak hukum dalam penanganan perkara pidana dengan pelaku Korporasi dan/atau Pengurus."

Akan tetapi, dalam rumusannya lebih lanjut tidak diatur mengenai indikator yang jelas terkait kapan suatu tindak pidana korporasi dapat ditanggung oleh korporasi atau pengurus korporasi, bahkan keduanya secara bersama-sama. Pasal 4 ayat (2) PERMA 13/2016 hanya mengatur mengenai dasar hakim dalam menilai kesalahan korporasi berdasarkan 3 (tiga) hal berikut, diantaranya:

1) Korporasi dapat memperoleh keuntungan atau manfaat dari tindak pidana tersebut atau tindak pidana tersebut dilakukan untuk kepentingan Korporasi;

2) Korporasi membiarkan terjadinya tindak pidana; atau

3) Korporasi tidak melakukan langkah-langkah yang diperlukan untuk melakukan pencegahan, mencegah dampak yang lebih besar dan memastikan kepatuhan terhadap ketentuan hukum yang berlaku guna menghindari terjadinya tindak pidana.

Melalui dasar tersebut, maka hakim akan menilai suatu perbuatan apakah benar dilakukan oleh korporasi atau tidak. Akan tetapi, dalam rumusan PERMA 13/2016 tidak diatur lebih lanjut mengenai pembebanan tanggungjawab kepada siapa apabila korporasi memenuhi dasar penilaian tersebut. Hal itu menimbulkan permasalahan, karena hakim tidak konsisten dalam menjatuhkan pertanggungjawaban pidana korporasi, ada yang menjatuhkan kepada pengurus, direksi, dan korporasi. Hal itu menimbulkan ketidakpastian hukum bagi masyarakat pencari keadilan. Oleh sebab itu, perlu dilakukan perbaikan pengaturan PERMA 13/2016 oleh Mahkamah Agung. Perbaikan itu dengan memasukan indikator yang jelas atas suatu perbuatan pidana korporasi, kapan dibebankan tanggungjawab pidananya kepada pengurus, korporasi, bahkan keduanya secara bersama-sama. Sehingga dengan indikator tersebut, hakim dalam mengadili perkara pidana lingkungan, akan menilai suatu perbuatan 
dapat dibebankan kepada pengurus, korporasi, bahkan keduanya secara bersama-sama.

b. Perubahan Undang-Undang No. 39 Tahun 2014 Tentang Perkebunan

Salah satu masalah dalam temuan putusan di atas, dalam perbuatan pembakaran hutan dan lahan, hakim tidak konsisten dalam menjerat pidana Terdakwa. Hal itu karena perbuatan serupa diatur dalam UU yang sama, yakni UU PPLH dan UU Perkebunan. Akan tetapi, ancaman hukuman denda yang diaturjustru berbeda. Kondisi tersebut menimbulkan ketidakpastian bagi masyarakat pencari keadilan, khususnya yang terdampak pembakaran hutan dan lahan. Oleh sebab itu, perlu dilakukan perbaikan dari tumpang tindih peraturan tersebut, melalui perubahan UU Perkebunan. Hal itu dengan menghapus Pasal 108 UU Perkebunan. Adapun alasan penghapusan tersebut karena 2 (dua) hal.

Pertama, ancaman hukuman pidana denda pembakaran hutan dan lahan yang tidak diatur batas minimalnya dalam UU Perkebunan. Ketiadaan batas minimal tersebut menyebabkan hakim menjatuhkan putusan pidana denda yang cenderung ringan pada perkara pembakaran hutan dan lahan. Sehingga tidak menimbulkan efek jera dan tidak sesuai dengan rasa keadilan masyarakat yang terdampak akibat perbuatan itu. Hal itu berbeda dengan pengaturan pidana pembakaran hutan dan lahan di UU PPLH, yang mengatur batas minimal pidana denda, yakni Rp. 3 Miliar.

Kedua, ancaman hukuman pidana penjara pembakaran hutan dan lahan yang tidak diatur batas minimalnya dalam UU Perkebunan. Hal tersebut seperti yang pertama, yakni hakim yang cenderung menjatuhkan pidana penjara ringan bagi Terdakwa, sehingga tidak menimbulkan efek jera dan rasa keadilan pada masyarakat yang terdampak. Kondisi tersebut berbeda dengan pengaturan pidana di UU PPLH, yang mengatur batas minimal penjara yakni 3 tahun.

Atas dua alasan urgensi tersebut, maka harus dilakukan penghapusan Pasal 108 UU Perkebunan. Selain itu, upaya tersebut dilakukan untuk mengatasi tumpang tindih peraturan pidana yang mengatur hal yang sama. Sehingga menimbulkan ketidakpastian hukum di masyarakat, 
mengenai UU mana yang digunakan dalam perbuatan tersebut.

c. Perubahan UU No. 32 Tahun 2009 tentang Perlindungan dan Pengelolaan Lingkungan Hidup

Seperti yang diuraikan di atas, bahwa salah satu permasalahan dalam UU PPLH adalah ketidakjelasan batasan pelanggaran pidana lingkungan dan administrasi lingkungan. Dimana pada praktiknya perbuatan yang seharusnya dihukum dengan mekanisme administrasi, justru menggunakan pidana lingkungan. Hal tersebut disebabkan diaturnya sanksi pidana dan administrasi lingkungan untuk satu perbuatan (menjalankan kegiatan usaha tanpa izin) dalam UU PPLH, yakni di Pasal 109 PPLH dan Pasal 80 ayat (2) UU PPLH.

Akan tetapi, UU PPLH tidak memberikan indikator atau syarat suatu perbuatan menjalankan kegiatan usaha tanpa izin apakah penegakan hukumnya melalui administrasi atau pidana. Hal itu menimbulkan tidak adanya kepastian hukum bagi masyarakat pencari keadilan, dengan adanya dualisme tersebut. Oleh sebab itu, perlu dilakukan perubahan UU PPLH, dengan memasukan indikator atau syarat tersebut. Sehingga dengan adanya indikator tersebut, akan menjadi pertimbangan penegak hukum (Kepolisian, PPNS, Kejaksaan, dan Hakim) dalam menangani perkara pidana lingkungan tersebut, apakah masuk administrasi atau pidana.

d. Penyusunan Surat Edaran Mahkamah Agung tentang Pedoman Pemidanaan Perkara Bidang Lingkungan Hidup

Surat Edaran Mahkamah Agung (SEMA) merupakan salah satu peraturan yang dikeluarkan oleh Mahkamah Agung untuk internal lembaganya. Kedudukan SEMA ditegaskan dalam Pasal 79 UndangUndang No. 14 Tahun 1985 tentang Mahkamah Agung, yang berbunyi:

"Mahkamah Agung dapat mengatur lebih lanjut hal-hal yang diperlukan bagi kelancaran penyelenggaraan peradilan apabila terdapat hal-hal yang belum cukup diatur dalam Undang-undang ini."

Kemudian keberadaan dan kedudukan SEMA juga diakomodir dalam Pasal 8 ayat (2) Undang-Undang Nomor 12 Tahun 2011 tentang Pembentukan Peraturan Perundang-Undangan Jo. UU No. 15 Tahun 2019. 
Dengan kedua dasar hukum tersebut, maka kedudukan SEMA sedemikian kuat dalam mengatur internal lembaga Mahkamah Agung.

Pedoman pemidanaan perkara bidang lingkungan merupakan salah satu SEMA yang dapat dibuat oleh Mahkamah Agung. SEMA tersebut bertujuan untuk menjaga konsistensi hakim dalam memeriksa, mengadili, dan memutus perkara pidana bidang lingkungan. Terlebih pada kasus-kasus tertentu, hakim di Mahkamah Agung tidak konsisten dalam menerapkan hukum, khususnya hukuman yang dijatuhkan. Hal yang terjadi pada kasus di Putusan No. 1367 K/Pid.Sus-LH/2016, dimana Terdakwa terbukti melakukan perbuatan pemanfaatan hutan lindung tanpa izin, namun hakim menyatakan bahwa perbuatan itu bukan sebagai tindak pidana. Sedangkan pada kasus di Putusan No. 2095 K/Pid.SusLH/2017, yang memiliki karakter perbuatan serupa, hakim Mahkamah Agung menyatakan itu sebagai tindak pidana, dan Terdakwa dijatuhi hukuman pidana penjara 1 tahun. Oleh sebab itu, perlu adanya SEMA pidana lingkungan, untuk memberikan pedoman dasar pertimbangan hakim dalam mengadili perkara pidana lingkungan.

\section{Simpulan}

Berlandaskan pada uraian tersebut di atas, maka dapat diambil 2 (dua) kesimpulan utama pada penelitian ini. Pertama, urgensi optimalisasi penegakan hukum pidana lingkungan melalui putusan hakim yang berkepastian karena beberapa sebab, diantaranya: ketidakjelasan pengaturan pertanggungjawaban pidana lingkungan oleh korporasi, ketidakjelasan pendakwaan pidana pembakaran hutan dan lahan, ketidakjelasan batasan antara pelanggaran pidana lingkungan dan administrasi lingkungan, dan ketidakjelasan pemidanaan pemanfaatan hutan lindung oleh warga setempat. Kedua, upaya yang dapat dilakukan dalam optimalisasi penegakan hukum pidana lingkungan melalui putusan hakim yang berkepastian diantaranya dengan beberapa hal, yakni: perbaikan Peraturan Mahkamah Agung No. 13 Tahun 2016 tentang Tata Cara Penanganan Tindak Pidana oleh Korporasi; Perubahan Undang-Undang No. 39 Tahun 2014 Tentang Perkebunan; perubahan UU No. 32 Tahun 2009 tentang Perlindungan dan Pengelolaan Lingkungan Hidup; dan penyusunan Surat Edaran Mahkamah Agung 
tentang Pedoman Pemidanaan Perkara Bidang Lingkungan Hidup. Sehingga dengan upaya-upaya tersebut, maka diharapkan usaha penegakan hukum pidana lingkungan secara optimal dapat optimal.

\section{Daftar Rujukan}

Apriyanto, A. S. (2014). Penegakan Hukum Pidana Lingkungan Oleh Direktorat Reserse Kriminal Khusus Kepolisian Daerah Riau Terhadap Pelaku Pembakaran Hutan Dan Lahan. Jurnal Online Mahasiswa Fakultas Hukum, 1(2), 14. https://jom.unri.ac.id/index.php/JOMFHUKUM/article/ view/4414

CNN Indonesia. (2019). Indonesia Jadi Negara Keempat Sumbang Kematian Karena Polusi. Cnnindonesia.Com. https://www.cnnindonesia.com/teknologi/ 20191220202504-199-458861/indonesia-jadi-negara-keempat-sumbangkematian-karena-polusi

Diab, A. L. (2014). PERANAN HUKUM SEBAGAI SOCIAL CONTROL, SOCIAL ENGINEERING DAN SOCIAL WELFARE. Jurnal Al-'Adl, 7(2), 53.

Erwin, Y. P. (2015). KAJIAN YURIDIS MENGENAI PELAKSANAAN EKSEKUSI DALAM PENGADILAN HUBUNGAN INDUSTRIAL. Jurnal Legislasi Nasional, 12(4), 5-6. https://e-jurnal.peraturan.go.id/index.php/ jli/article/view/421

Greenpeace Indonesia. (2020). Tantangan kita bersama di tahun 2020. Greenpeace. Org. https://www.greenpeace.org/indonesia/cerita/4544/tantangan-kitabersama-di-tahun-2020/

Ilham, M.H.(2018). KAJIANATAS ASASPERADILANCEPAT, SEDERHANA, DAN BIAYA RINGAN TERHADAP PEMENUHAN HAK PENCARI KEADILAN. Jurnal Verstek, 7(3), 213.

LeIP. (2020). Laporan Kajian Putusan Perkara Lingkungan Hidup. Lembaga Kajian dan Advokasi Independensi Peradilan (LeIP).

Machmudin, D. D. (2015). Optimalisasi Peran Hakim Agung dalam Penyelesaian Perkara Kasasi dan Peninjauan Kembali. Jurnal Konstitusi, 12(2), 398-399. https://jurnalkonstitusi.mkri.id/index.php/jk/article/ view/1229/68

Marzuki, P. M. (2011). Penelitian Hukum. Kencana Prenada Media Group.

Mubarok, N. (2019). Penegakan Hukum Pidana Lingkungan di Indonesia. Jurnal Hukum Pidana Islam, 5(1), 26.

Puspita, L. (2018). Optimalisasi Penegakan Hukum Pidana Di Bidang 
Lingkungan Hidup Melalui Prinsip Primum Remedium. INA-Rxiv, 7. https://doi.org/10.31227/osf.io/epy6n

Rahardjo, S. (2009). Penegakan Hukum: Suatu Tinjauan Sosiologis. Genta Publishing.

Sevilla, C. (1993). Pengantar Metode Penelitian.

Tim Publikasi. (2019). Infografik: Perbanyak Sumber Energi, Kurangi Emisi Karbon. Katadata.Co.Id. https://katadata.co.id/timpublikasikatadata/ infografik/5e9a4c572d6b8/infografik-perbanyak-sumber-energi-kurangiemisi-karbon

Widowati, H. (2019). Polusi Udara Sebabkan 7 Juta Kematian per Tahun di Dunia. Katadata.Co.Id. https://databoks.katadata.co.id/datapublish/2019/06/07/ polusi-udara-sebabkan-7-juta-kematian-per-tahun-didunia\#: :text=Polusi udara menyebabkan 26\%25 kematian,29\%25 kanker paru-paru 